\title{
Total mercury and methylmercury (MeHg) in braised and crude Boletus edulis carpophores during various developmental stages
}

\author{
Jerzy Falandysz ${ }^{1}(\mathbb{D}) \cdot$ Martyna Saba $^{2} \cdot$ Małgorzata Rutkowska $^{3} \cdot$ Piotr Konieczka $^{3}$
}

Received: 11 July 2020 / Accepted: 5 August 2021 / Published online: 12 August 2021

(C) The Author(s) 2021

\begin{abstract}
We collected and processed Boletus edulis (King Bolete) carpophores grouped in four batches based on their developmental stage (button stage, young — white, large — white, and large - yellow). The study aimed, for the first time, to examine the B. edulis content and effect of braising and to estimate the intake of total mercury (THg) and methylmercury (MeHg) from a single meal based on whole (wet) weight (ww) and dry weight (dw). In braised carpophores, THg concentrations ranged from $0.2668 \pm$ 0.0090 to $0.5434 \pm 0.0071 \mathrm{mg} \mathrm{kg}^{-1} \mathrm{ww}$ at different developmental stages, whereas crude products concentrations ranged from $0.1880 \pm 0.0247$ to $0.2929 \pm 0.0030 \mathrm{mg} \mathrm{kg}^{-1}$ ww. The button stage crude carpophores were more highly contaminated with $\mathrm{THg}$ than at later stages of maturity, but MeHg levels were lower $(p<0.0001)$. On the other hand, braised button stage carpophores showed more $\mathrm{MeHg}$ than at later maturity stages. $\mathrm{MeHg}$ contributed at $1.9 \pm 0.7 \% \mathrm{in} \mathrm{THg}$ in crude mushrooms and at $1.4 \pm 0.3 \%$ in braised meals. The effect of braising was to increase the average THg and $\mathrm{MeHg}$ contents in fresh mushroom meals by $52 \pm$ $31 \%$ and $53 \pm 122 \%$ respectively, but a reduction of $40 \pm 14 \%$ and $40 \pm 49 \%$ respectively was seen on a dw basis. The potential intakes of THg and $\mathrm{MeHg}$ from braised meals of $B$. edulis studied were small and considered safe.
\end{abstract}

Keywords Culinary processing $\cdot$ Food toxicology $\cdot$ Forest $\cdot$ Fungi $\cdot$ Mushrooms $\cdot$ Wild food

Highlights

- First study on $\mathrm{MeHg}, \mathrm{THg}$, and the effects of braising in B. edulis

- $\mathrm{MeHg}$ contribution to THg in crude mushrooms was 1.0-3.3\%

- $\mathrm{MeHg}$ contribution to THg in braised mushrooms was $0.8-1.7 \%$

- Braised mushrooms in wet weight were higher in THg and result for $\mathrm{MeHg}$ varied

- The MeHg and THg intakes from braised B. edulis were estimated

Responsible Editor: Philippe Garrigues

Jerzy Falandysz

jerzy.falandysz@gmail.com

1 Department of Toxicology, Faculty of Pharmacy, Medical University of Lodz, 1 Muszyńskiego Street, 90-151 Łódź, Poland

2 Laboratory of Environmental Chemistry and Ecotoxicology, Faculty of Chemistry, University of Gdańsk, 63 Wita Stwosza Street, 80-308 Gdańsk, Poland

3 Department of Analytical Chemistry, Faculty of Chemistry, Gdańsk University of Technology, 11/12 G. Narutowicza Street, 80-233 Gdańsk, Poland

\section{Introduction}

Boletus edulis Fr. is a prized edible wild mushroom with many common names in different languages, including, Borowik szlachetny (boletus noble), Cep, Cèpes, King Bolete, Porcini, Prawdziwek (true mushroom), Steinpilz (stone mushroom), Stensopp (stone mushroom), Penny Bun, and more. This diversity of names reflects the geographical extent of the appreciation and value of this food which is a target of foragers as well as recreational mushroom pickers. B. edulis and the Lactarius deliciosus (L.) Gray (tasty in Latin) are among the mushrooms mentioned by Adam Mickiewicz, the National Guard of the time, in a colorful description of the mushrooming habit in the Polish national epic poem, the "Pan Tadeusz," published in 1834.

The King Bolete forms relatively easily recognizable carpophores (fruiting bodies; Fig. 1). It forms mycorrhizal relationships with conifers, primarily spruce Picea abies (L.) H.Karst, pine Pinus sylvestris L., and birch Betula spp. (Gumińska and Wojewoda 1985). Carpophores of B. edulis are considered highly nutritious and, with a moisture content 


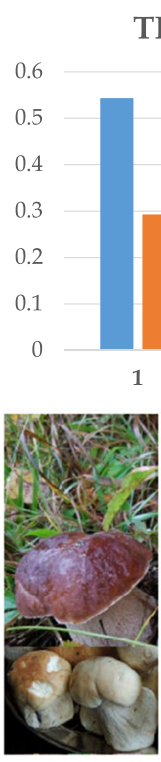

1. Button (31 g)
THg (mg kg-1 whole weight)

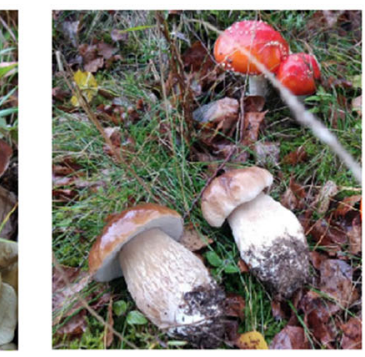

2. Young - white (73 g)
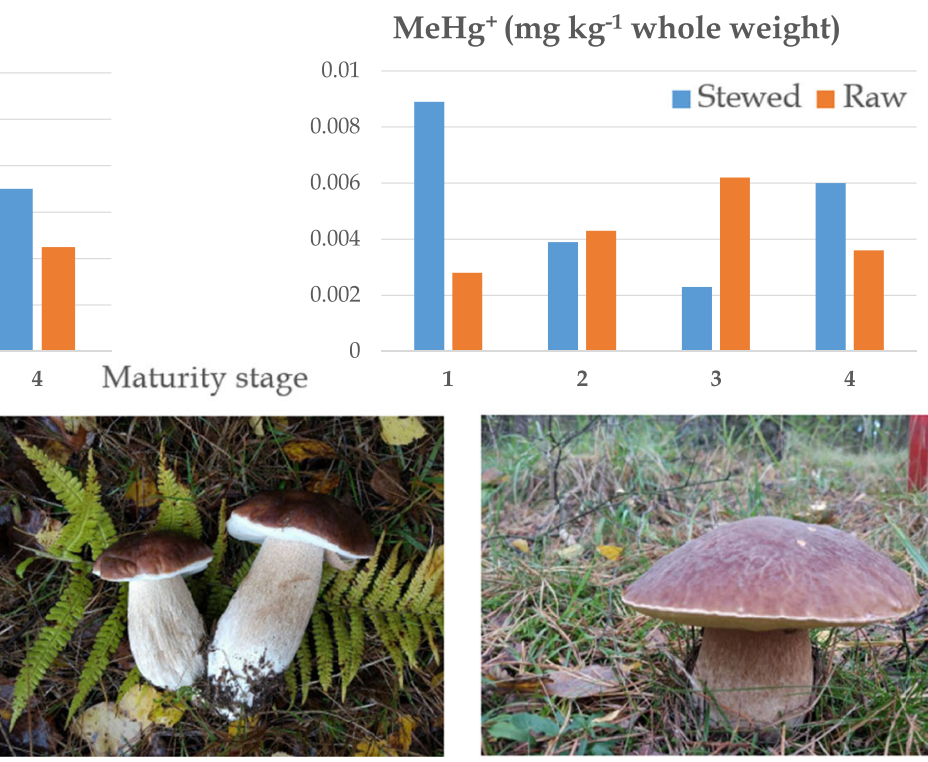

3. Large - white (133 g)

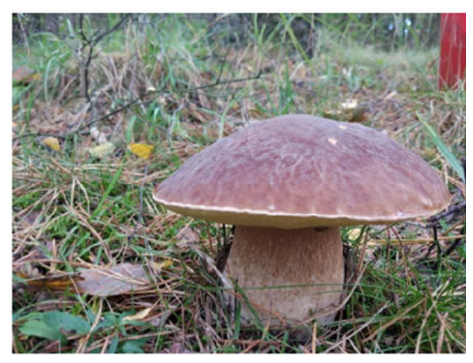

4. Large - yellow (adult, $128 \mathrm{~g}$ )

Fig. 1 Graphical representation of the stages of maturity of the B. edulis tested and of $\mathrm{THg}$ and $\mathrm{MeHg}$ data in products

of $90 \%$ in fresh specimens (Table 1) as seen in the study by Stijve and Roschnik (1974). A recent study (Heleno et al. 2015) has characterized a number of nutrients and other organics in B. edulis:

- Carbohydrates (mostly in the form of undigestible chitin, which has a fiber-like role in human bowel function) in dried fruiting bodies, accounted for $81.86 \pm 0.41 \%$

- Proteins at $10.65 \pm 0.47 \%$

- Fatty acids (polyunsaturated predominate over mono- and saturated) including palmitic, stearic, oleic, linoleic, and alfa linolenic acid and eighteen other less abundant fatty acids (total fat content was at $2.23 \pm 0.02 \%$ )

- Free sugars such as fructose at $0.71 \pm 0.33 \%$, glucose at $1.24 \pm 0.46 \%$, mannitol at $3.14 \pm 1.18$, and trehalose at $9.29 \pm 0.51 \%$

- Tocopherols such as $\alpha$-tocopherol and $\beta$-tocopherol

- Organic acids such as oxalic acid and fumaric acid (no quinic, malic, or citric acids)
- And phenolic compounds such as protocatechuic acid, $p$ hydroxybenzoic acid $p$-coumaric acid

The antioxidant properties of methanol extracts from dried $B$. edulis relating to phenolic compounds and tocopherols were associated largely with radicals scavenging activity and reducing power and less to lipid peroxidation or $\beta$-carotene bleaching inhibition (Heleno et al. 2015).

B. edulis is also relatively rich in important inorganic constituents and particularly in selenium (Se), occurring in the range from 4.1 to $63 \mathrm{mg} \mathrm{kg}^{-1}$ dry weight (mean weighted content is at around $20 \mathrm{mg} \mathrm{kg}^{-1} \mathrm{dw}$ ) in specimens foraged from European and North American habitats (Falandysz 2013). Mean Se in the caps of B. edulis from Poland was in the range $8.7 \pm 8.9$ to $32 \pm 20 \mathrm{mg} \mathrm{kg}^{-1} \mathrm{dw}$ (Falandysz et al. 2008). The zinc ( $\mathrm{Zn}$ ) content in caps ranges from $120 \pm 30$ to $210 \pm 60 \mathrm{mg} \mathrm{kg}^{-1} \mathrm{dw}$, copper $(\mathrm{Cu})$ from $25 \pm 11$ to $64 \pm 27 \mathrm{mg}$ $\mathrm{kg}^{-1} \mathrm{dw}$, and iron (Fe) from $34 \pm 10$ to $110 \pm 90 \mathrm{mg} \mathrm{kg}^{-1} \mathrm{dw}$.
Table 1 Summary of data on the samples size, biomass (whole weight; ww), and moisture content of the fungal materials

\begin{tabular}{|c|c|c|c|c|}
\hline \multirow{2}{*}{$\begin{array}{l}\text { Developmental stage of carpophore and } \\
\text { number of the specimens }\end{array}$} & \multicolumn{2}{|c|}{ Stewed carpophores } & \multicolumn{2}{|c|}{ Crude (control) carpophores } \\
\hline & $\begin{array}{l}\text { Biomass (g; } \\
\text { ww) }\end{array}$ & $\begin{array}{l}\text { Moisture } \\
\text { content (\%) }\end{array}$ & $\begin{array}{l}\text { Biomass (g; } \\
\text { ww) }\end{array}$ & $\begin{array}{l}\text { Moisture } \\
\text { content (\%) }\end{array}$ \\
\hline Button stage $(n=19)$ & 233.7 & 75.5 & 231.0 & 90.0 \\
\hline Young-white $(n=8)$ & 242.4 & 74.3 & 245.5 & 90.0 \\
\hline Large-white $(n=3)$ & 185.8 & 76.5 & 190.6 & 90.1 \\
\hline Large-yellow $(n=4)$ & 241.8 & 73.1 & 238.2 & 90.1 \\
\hline Mean & $225.9 \pm 23.4$ & $74.8 \pm 1.3$ & $226.3 \pm 21.2$ & $90.0 \pm 0.0$ \\
\hline
\end{tabular}


Stems have relatively lower contents than the caps-around twice less in $\mathrm{Zn}, \sim 2$ to 3-fold less in $\mathrm{Cu}$ and up to 2-fold lower in Fe (Falandysz et al., 2008 and 2011; Frankowska et al. 2010). B. edulis effectively bio-concentrates minerals as $\mathrm{Cu}$, $\mathrm{Zn}$, potassium $(\mathrm{K})$, and magnesium $(\mathrm{Mg})$ in its carpophores (Falandysz et al. 2011). It bio-excludes lead $(\mathrm{Pb})$ and contamination levels are typically below $2 \mathrm{mg} \mathrm{kg}^{-1} \mathrm{dw}$ (Falandysz et al. 2008; Širić et al. 2017), but it strongly bio-concentrates $\mathrm{Cd}$ and typical contamination levels are up to $10 \mathrm{mg} \mathrm{kg}^{-1} \mathrm{dw}$ in caps (Falandysz et al. 2011; Širić et al. 2017).

Mercury is naturally dispersed in trace amount in the Earth's crust and soils may be regionally enriched in this element due to specific geological history (Gustin et al. 1999). Forest ecosystems play a key role in biogeochemical cycling of Hg (Falandysz 2017; Zhou et al. 2020). It has been documented in studies that forest soil is a source of $\mathrm{Hg}$ for a diversity of macrofungi, which is found to be relatively resistant to accumulation in the sclerotia (a dense mass of mycelia that is buried underground) formed by some wood decaying subtropical fungi such as Wolfiporia cocos (F.A. Wolf) Ryvarden and Gilb., or Pleurortus tuber-regium (Rumph. ex Fr.) Singer (Alonso et al. 2000; Árvay et al. 2014; Bargagli and Baldi 1984; Falandysz et al. 2001, 2002, 2013, 2020b; Jarzyńska et al. 2012; Kavčič et al. 2019; Kojta et al. 2015; Krasińska and Falandysz 2016; Melgar et al. 2009; Nasr and Arp 2011; Nnorom et al. 2013; Rieder et al. 2011; Saba et al. 2016; Širić and Falandysz 2020; Wiejak et al. 2016).

Wild mushrooms accumulate the largest amount of $\mathrm{Hg}$ in the terrestrial environment. Mercury has been found at up to $22 \mathrm{mg} \mathrm{kg}^{-1} \mathrm{dw}$ in caps and in $8.4 \mathrm{mg} \mathrm{kg}^{-1} \mathrm{dw}$ in stems of Boletus bainiugan Dentinger, from anthropogenically unpolluted region of Yunnan (China), which is a land with largely geogenic $\mathrm{Hg}$ in forest topsoils with concentrations of $3.4 \mathrm{mg}$ $\mathrm{kg}^{-1} \mathrm{dw}$ (Falandysz et al. 2015). Mushrooms collected from former cinnabar $(\mathrm{HgS})$ mining and smelting areas in Slovakia showed a maximal $\mathrm{Hg}$ concentration up to $470 \mathrm{mg} \mathrm{kg}^{-1} \mathrm{dw}$ in Lactarius quietus (Fr.) Fr., (Árvay et al. 2014). In the case of B. edulis, concentrations up to $100 \pm 8 \mathrm{mg} \mathrm{kg}^{-1} \mathrm{dw}$ have been reported in young carpophores from the $\mathrm{HgS}$ mining area in Slovenia (Kavčič et al. 2019). B. edulis has a high potential to bioconcentrate $\mathrm{Hg}$ and "typical" contamination levels in specimens from European specimens were in the range 1.2 \pm 1.4 to $7.6 \pm 3.1 \mathrm{mg} \mathrm{kg}^{-1} \mathrm{dw}$ in caps and from $0.84 \pm 0.74$ to $3.8 \pm$ $1.5 \mathrm{mg} \mathrm{kg}^{-1} \mathrm{dw}$ in stems (Falandysz et al. 2003 and 2007; Gucia and Falandysz 2003; Kojta and Falandysz 2016; Melgar et al. 2009; Širić et al. 2017). In Canada, Hg in the whole carpophores of $B$. edulis has been determined at $2.8 \pm$ $1.6 \mathrm{mg} \mathrm{kg}^{-1} \mathrm{dw}$ (total range $0.46-5.8 \mathrm{mg} \mathrm{kg}^{-1} \mathrm{dw}$ ) (Nasr et al. 2012).

Methylmercury $(\mathrm{MeHg})$ contributed up to $16.1 \%$ in total $\mathrm{Hg}(\mathrm{THg})$ in carpophores of several species of edible and inedible fungi studied in Europe, Asia (China), and North America (USA) (Bargagli and Baldi 1984; Fischer et al.
1995; Rieder et al. 2011; Rutkowska et al. 2021; Stijve and Roschnik 1974). In B. edulis the contribution of MeHg to THg in carpophores investigated thus far was $14 \%$ (THg concentration of $1.9 \mathrm{mg} \mathrm{kg}^{-1} \mathrm{dw}$ ) (Bargagli and Baldi 1984). Kavčič et al. did not detect $\mathrm{MeHg}$ at concentration exceeding its contribution at above $5 \%$ in a set of B. edulis samples from the unpolluted and polluted (cinnabar mine) sites in Slovenia.

$\mathrm{MeHg}$ is of concern because of its persistence, strong bioavailability in foods and high toxicity and is therefore of particular health and environmental relevance. In the environment, it is biosynthesized from $\mathrm{Hg}(\mathrm{II})$ in minute amounts by some anaerobic methylating bacteria (sulfate-reducing species) in anoxic condition in sediment, water columns and suspended particles, and soil (Schwesig et al. 1999; Xu et al. 2019). MeHg can possibly also be produced by microaerophilic nitrite-oxidizing bacteria Nitrospina in oxic condition in subsurface oceanic waters (Villar et al. 2020).

Thus, $\mathrm{Hg}$ in low concentrations is a notorious contaminant of both, vegetarian and nonvegetarian diets. Within nonvegetarian foods, it occurs at lowest levels in farmed livestock and at higher levels in game, but the highest focus is on its presence in fish and seafood (Le Croizier et al. 2020; Nawrocka et al. 2020; Petrova et al. 2020). The exposure to $\mathrm{Hg}$ and its effects in human are largely linked to the occurrence of $\mathrm{MeHg}$ in the muscle tissues of marine fish and other seafood, where it is a major or almost the sole $\mathrm{Hg}$ compound (Brambilla et al. 2013).

$\mathrm{MeHg}$ undergoes a pronounced biomagnification in aquatic environment food webs. A tragic history of contamination with $\mathrm{MeHg}$ of seafood in the Minamata Bay, which in the period from 1951 to 1968 become heavy polluted with $\mathrm{MeHg}$ and $\mathrm{Hg}(\mathrm{II})$ discharged in industrial sludge, highlighted the neurotoxic nature of $\mathrm{MeHg}$ in exposed humans and cats, in the early 1950s (Harada 1995; Falandysz et al. 2020a). A major target for absorbed MeHg in humans is selenium (Se) in selenoenzymes (e.g., thioredoxin reductases 1 and 2, glutathione peroxidase 4), which otherwise prevents and reverses oxidative damage in the brain (Ralston and Raymond 2018; Spiller 2018). Thus, the co-occurrence of $\mathrm{Hg}$ and $\mathrm{MeHg}$ with Se and its forms in foods or in a wider sense in any environmental material is important when considering intake rates and possible effect in exposed individuals.

B. edulis is considered as an excellent ingredient in many recipes, where fresh carpophores are braised, sautéed, or fried, while button stage and young specimens with firm and crunchy flesh are especially valued for pickling. Large size and older specimens are considered more suitable for drying as they are already partially dehydrated. After removing the pore layer, B. edulis is also considered good for preserving dry and its flavor can be enhanced when reconstituted by soaking (15 $\mathrm{min}$ ) in warm water, squeezed dry, and pureed. The water used for soaking (macerate) should to be reserved according to a traditional recipe and used, which can raise a dilemma as 
water extracts may contain an excess of radiocaesium $\left({ }^{134 /}\right.$

${ }^{137} \mathrm{Cs}$ ) depending on the location of collection (Falandysz et al. 2021a; Saba and Falandysz 2021). Dried mushrooms can be consumed whole when rehydrated or they can be also powdered and soaked for use in a crème soup or sauce.

The culinary processing of mushrooms including household or industrial treatment has a basic effect on their sensory and nutritional features, but the amount of information on the impact of processing on content and forms of mineral constituents in mushroom products and meals is limited. This is despite the high biodiversity of wild species that are consumed reaching around 2000 for edibles worldwide, but also despite the tens of dozens of processing recipes, both traditional and modern (Drewnowska et al. 2017). As already mentioned, there is only a handful of literature on the speciation of $\mathrm{Hg}$ in mushrooms and similarly on the effects of culinary processing, i.e., blanching or blanching and pickling on fate of $\mathrm{THg}$, and on occurrence in fried mushrooms (Falandysz and Drewnowska 2015 and 2017; Falandysz et al. 2019a, 2019b; Svoboda et al. 2002). There is no previous data on the impact of a culinary treatment on the fate of $\mathrm{MeHg}$ in mushrooms or the impact of braising on the fate of both, MeHg and THg, and on possible human exposure. The objective of this study was to investigate and present data on the effects of braising on $\mathrm{THg}$ and $\mathrm{MeHg}$ content and fate in B. edulis mushrooms at various developmental stages and also assesses dietary intake in view of existing recommendations on safe exposure.

\section{Materials and methods}

Samples of the carpophores of B. edulis were collected from an unpolluted forested area (near the villages of Pomlewo and Szklana Góra) at ca 30-50 km southwest of the cities of Gdańsk, Sopot, and Gdynia (Gdańsk coordinates: 54 $13^{\circ} 7^{\prime \prime} \mathrm{N}$ $\left.18^{\circ} 21^{\prime} 28^{\prime \prime} \mathrm{E}\right)$. The sampling points were in areas predominated with Downy birch Betula pubescens Ehrh., and from mixed areas of the Common oak Quercus robur L., and Scots pine Pinus sylvestris L., with incursions of Downy birch and Norway spruce Picea abies (L.) H. Karst (Falandysz et al. 2021b).

The nearest potential area of contamination to the sampling site in the past is a nonferrous smelter situated ca $27 \mathrm{~km}$ southeast of the forest and with a largely unreported history of production (Falandysz 2016). However, as the dominating wind direction is westerly with a proportion from the south during the summer months, the impact of the smelter or the nearby city of Gdańsk is likely to be negligible if at all.

All carpophores were in excellent body condition and were collected within a few hours in the early morning of October, 2019. They were cleaned on site from any substrate debris with a ceramic knife. The maturity was assessed visually and each specimen was assigned to and pooled in one of four groups depending on the developmental stage (Fig. 1) and weighed (Table 1). Group "1" consisted of carpophores at the button stage and contained nineteen individuals in the pool (average biomass $31 \mathrm{~g}$ wet weight per specimen), group " 2 " contained eight young specimens with white hymenophore (average biomass $73 \mathrm{~g}$ wet weight per specimen), group " 3 " contained three large specimens with white hymenophore (average biomass $133 \mathrm{~g}$ wet weight per specimen), and group " 4 " included four large (mature - spreading spores) individuals with yellow hymenophore (average biomass $128 \mathrm{~g}$ wet weight per specimen) (Graphical abstract, Table 1).

Each carpophore was split vertically, using a ceramic knife, into two parts that were further grouped accordingly (Table 1) and processed as pooled (composite) samples (Falandysz et al. 2021b). Altogether two pooled samples per group were created in parallel giving a total of eight pooled samples. One set of halves from each developmental stage group was used for the braising experiments and the other set served as a control material for calculations and as a reference to the effects of braising on a whole weight basis.

The set of control samples were chopped into small pieces and dried at $65^{\circ} \mathrm{C}$ for $24 \mathrm{~h}$ using plastic vegetable drying trays and a commercial dryer, then ground to a fine powder using a blender with ceramic blades and plastic container. Depending on the development stage group, the biomass of this set of carpophores ranged from 190.6 to $245.5 \mathrm{~g}$ for the whole weight, corresponding to 19.2 to $24.5 \mathrm{~g}$ for the dried samples.

The moisture content of the pooled control materials was determined gravimetrically from the difference in biomass weight for fresh and dehydrated materials. The pulverized fungal materials were transferred to tightly sealed plastic bottles (Wide-Mouth Opaque Amber HDPE Packaging Bottles with Caps, Thermo Scientific ${ }^{\mathrm{TM}}$ Nalgene ${ }^{\mathrm{TM}}$ ) and stored under dry and clean conditions at room temperature until further analyses.

The halves of carpophores subjected for braising were chopped into pieces of circa $3 \times 3 \mathrm{~cm}$ within each pool. Each pool of chopped mushrooms was placed in a ceramic coated metal pot (capacity $1 \mathrm{~L}$ ) with a glass lid with an aperture. The pots were placed on inductive cookers and gently braised with a portion of fat (a mix of butter and olive oil; 1:1; Falandysz et al. 2021b) for $30 \mathrm{~min}$ from the time when the contents reached "boiling" point. These freshly braised mushroom meals were transferred, using a ceramic spoon, into tared plastic containers and weighed. Next, the braised products were deep frozen at $-24{ }^{\circ} \mathrm{C}$ and lyophilised for $72 \mathrm{~h}$ (Labconco Freeze Dry System, Kansas City, MO, USA). The moisture content of the braised fungal materials was determined gravimetrically from the difference in biomass weight between the fresh and lyophilised products. The dehydrated products were ground into a powder using a blender with ceramic blades and plastic container and stored in tightly closed plastic bottles (Wide-Mouth Opaque Amber 
HDPE Packaging Bottles with Closure, Thermo Scientific ${ }^{\mathrm{TM}}$ Nalgene $^{\mathrm{TM}}$ ) under dry and clean conditions at room temperature until analysis. The contents of $\mathrm{Hg}$ and $\mathrm{MeHg}$ were determined in fully dehydrated materials and calculated both on a dry and whole (wet) weight basis.

Data for the braised products were not corrected for added and sorbed by mushrooms fat content, which may provide, to some extent, a "diluting" effect on the content of $\mathrm{Hg}$ and $\mathrm{MeHg}$ in the mushroom meals obtained. In addition to fat, traditional recipes for braising mushrooms usually require water, table salt and also cream, onion and black pepper or other spices. However, for these experiments, apart from butter and olive oil, nothing else was added to the stew.

The THg and $\mathrm{MeHg}$ contents of the fungal materials in this study were determined using a modification of the method by Maggi et al. (2009). It relays on atomic absorption spectroscopy after a thermal decomposition treatment under preset conditions (Mercury/MA-3000 Mercury Analyser supplied by Nippon Instruments Corporation (NIC, Japan). MeHg was extracted by hydrolysis with hydrobromic acid ( $\mathrm{HBr})$ and then sequentially extracted with toluene and L-cysteine (Rutkowska et al. 2021). A free Social Science Statistics software (www.socscistatistics.com) and Microsoft Excel (2013 edition) were used for a basic statistical analyses of the results and including Mann-Whitney $U$ test, and for illustrations.

\section{Results and discussion}

The moisture content of the unprocessed carpophore in the various stages of development ranged from 90.0 to $90.1 \%$ with a mean content at $90.0 \pm 0.0 \%$, while that of the braised products ranged from 73.1 to $76.5 \%$ with a mean of $74.8 \pm$ $1.3 \%$ (Table 1). Individual data on THg and MeHg concentrations in culinary processed and unprocessed $B$. edulis for the different developmental stages and the net effect of braising (\%) based on the whole (wet) and dry weight are detailed in Tables 2 and 3.
THg, braising, and carpophore developmental pattern

Total Hg concentration in braised carpophores in the whole (wet) weight for the developmental stages was in the range from $0.2668 \pm 0.0090$ to $0.5434 \pm 0.0071 \mathrm{mg} \mathrm{kg}^{-1}$ whole (wet) weight (ww). The mean error for all maturity stages altogether was $0.3604 \pm 0.0915 \mathrm{mg} \mathrm{kg}^{-1}$ ww. THg in the unprocessed (raw) carpophores ranged from $0.1880 \pm$ 0.0247 to $0.2929 \pm 0.0030 \mathrm{mg} \mathrm{kg}^{-1}$ ww with an overall mean of $0.2373 \pm 0.0308 \mathrm{mg} \mathrm{kg}^{-1}$ ww (Table 2). Both raw and braised button stage carpophores were more contaminated with $\mathrm{THg}$ than those at higher maturity stages, on a dry weight as well as whole weight basis ( $p<0.0001 ; \mathrm{M}-\mathrm{W} U$ test). It has to be pointed out that results for braised carpophores were not corrected for the amount of fat absorbed during braising which would have a slightly diluting effect. The tested fats (butter and olive oil) showed no detectable content of THg (method limit of detection was close to $0.001 \mathrm{mg} \mathrm{kg}^{-1}$ and method limit of quantification was close to $0.003 \mathrm{mg} \mathrm{kg}^{-1}$ ) (Rutkowska et al. 2021). The increase in THg concentration in braised carpophores can be explained by the partial decline in moisture content during braising and the resulting shrinkage of the fungal matrix accompanied by the preferential retention of a portion of THg. In other words, to obtain a portion of $100 \mathrm{~g}$ braised carpophores of $B$. edulis, a higher amount of fresh carpophores would be required. The braising process resulted in an increase in $\mathrm{THg}$ concentration of the mushroom meal products from 9.6 to $85 \% \mathrm{ww}$ (mean: $52 \% \pm 31 \% \mathrm{ww}$ ) across all the developmental stages studied.

The crude, dehydrated carpophores showed THg concentrations in the range from $1.899 \pm 0.025$ to $2.929 \pm 0.030 \mathrm{mg}$ $\mathrm{kg}^{-1} \mathrm{dw}$, across all developmental stages, with an overall mean of $2.383 \pm 0.298 \mathrm{mg} \mathrm{kg}^{-1} \mathrm{dw}$ (Table 2). If fully dehydrated fungal material weights are used as a basis to estimate the effect of braising, the reduction of $\mathrm{THg}$ content was $24 \%$ for the button stage group and from 37 to $57 \%$ for higher maturity stages (total by $40 \pm 14 \%$ ). This would be expected as the THg content of the lyophilized raw B. edulis samples increased tenfold due to the removal of moisture.

Table 2 Total mercury in stewed and crude B. edulis carpophore for developmental stages ( $\left.\mathrm{mg} \mathrm{kg}^{-1} \mathrm{ww} \mathrm{and} \mathrm{mg} \mathrm{kg}^{-1} \mathrm{dw}\right)$ and effect of stewing (\%)

\begin{tabular}{|c|c|c|c|c|c|c|}
\hline Developmental stage & $\begin{array}{l}\text { Stewed } \\
\mathrm{mg} \mathrm{kg}^{-1} \text { ww }\end{array}$ & $\begin{array}{l}\text { Crude } \\
\mathrm{mg} \mathrm{kg}^{-1} \mathrm{ww}\end{array}$ & $\begin{array}{l}\text { Effect } \\
\%\end{array}$ & $\begin{array}{l}\text { Stewed } \\
\mathrm{mg} \mathrm{kg}^{-1} \mathrm{dw}\end{array}$ & $\begin{array}{l}\text { Crude } \\
\mathrm{mg} \mathrm{kg}^{-1} \mathrm{dw}\end{array}$ & $\begin{array}{l}\text { Effect } \\
\%\end{array}$ \\
\hline Button stage & $0.5434 \pm 0.0071$ & $0.2929 \pm 0.0030$ & +85 & $2.218 \pm 0.029$ & $2.929 \pm 0.030$ & 24 \\
\hline Young-white & $0.2668 \pm 0.0090$ & $0.2434 \pm 0.0014$ & +9.6 & $1.038 \pm 0.035$ & $2.434 \pm 0.014$ & -57 \\
\hline Large — white & $0.2813 \pm 0.0035$ & $0.1880 \pm 0.0247$ & +50 & $1.197 \pm 0.015$ & $1.899 \pm 0.025$ & -37 \\
\hline Large-yellow & $0.3502 \pm 0.0023$ & $0.2249 \pm 0.0016$ & +56 & $1.302 \pm 0.008$ & $2.272 \pm 0.016$ & -42 \\
\hline All & $0.3604 \pm 0.0915$ & $0.2373 \pm 0.0308$ & $52 \pm 31$ & $1.439 \pm 0.390$ & $2.383 \pm 0.298$ & $40 \pm 14$ \\
\hline
\end{tabular}

Notes: * Data not corrected for hidden fatty residue adsorbed by carpophore, what had a weak diluting effect 
Table 3 Methylmercury in stewed and crude B. edulis carpophore for developmental stages ( $\mathrm{mg} \mathrm{kg}^{-1} \mathrm{ww}$ and dw), effect of stewing (\%), and contribution of $\mathrm{MeHg}$ in $\mathrm{THg}$ content $(\%)$

\begin{tabular}{|c|c|c|c|c|c|c|c|c|}
\hline Developmental stage & $\begin{array}{l}\text { Stewed } \\
\mathrm{mg} \mathrm{kg}^{-1} \text { ww }\end{array}$ & $\begin{array}{l}\text { Crude } \\
\mathrm{mg} \mathrm{kg}^{-1} \text { ww }\end{array}$ & $\begin{array}{l}\text { Effect } \\
\%\end{array}$ & $\begin{array}{l}\text { Stewed } \\
\mathrm{mg} \mathrm{kg}^{-1} \mathrm{dw}\end{array}$ & $\begin{array}{l}\mathrm{MeHg} \text { in } \mathrm{THg} \\
\%\end{array}$ & $\begin{array}{l}\text { Crude } \\
\mathrm{mg} \mathrm{kg}^{-1} \mathrm{dw}\end{array}$ & $\begin{array}{l}\mathrm{MeHg} \text { in } \mathrm{THg} \\
\%\end{array}$ & $\begin{array}{l}\text { Effect }{ }^{*} \\
\%\end{array}$ \\
\hline Button stage & $0.0089 \pm 0.0001$ & $0.0028 \pm 0.0000$ & +218 & $0.0364 \pm 0.0006$ & 1.6 & $0.0285 \pm 0.0003$ & 1.0 & +28 \\
\hline Young-white & $0.0039 \pm 0.0000$ & $0.0043 \pm 0.0007$ & -9.3 & $0.0152 \pm 0.0001$ & 1.5 & $0.0431 \pm 0.0007$ & 1.8 & -65 \\
\hline Large-white & $0.0023 \pm 0.0016$ & $0.0062 \pm 0.0000$ & -63 & $0.0097 \pm 0.0067$ & 0.8 & $0.0622 \pm 0.0005$ & 3.3 & -84 \\
\hline Large-yellow & $0.0060 \pm 0.0000$ & $0.0036 \pm 0.0000$ & +67 & $0.0223 \pm 0.0002$ & 1.7 & $0.0363 \pm 0.0002$ & 1.6 & -39 \\
\hline All & $0.0053 \pm 0.0022$ & $0.0042 \pm 0.0010$ & $+53 \pm 122$ & $0.0209 \pm 0.0084$ & $1.4 \pm 0.3$ & $0.0425 \pm 0.0101$ & $1.9 \pm 0.7$ & $-40 \pm 49$ \\
\hline
\end{tabular}

Notes: ${ }^{*}$ Results not corrected for content of fatty residue adsorbed by carpophore, what had a weak diluting effect

The partial removal of $\mathrm{Hg}$ from a fungal substrate during the braising experiment is possible because of suspected co-distilling with water vapor and other volatiles through the hole in a glass lid. Further minor losses may also arise due to condensation (deposition) on the inner surface of the lid as well as absorption by the oily film and a small amount of residual fat remaining on the internal surface of the pot after transfer of the braised mushroom meal. An increase of $\mathrm{Hg}$ content in braised mushrooms if expressed on dry weight basis could only be possible if a fortification of the meal with $\mathrm{Hg}$ from an external source took place.

There is some comparative data on the $\mathrm{Hg}$ content in mushrooms at some developmental stages in the scientific literature. For example, Seeger (1976) noted that in Agaricus campester (current name A. campestris L.many names and varieties for this mushroom are available from the Index Fungorum web site), Agaricus silvicola (current name A. silvicolae-similis Bohus and Locsmándi), and B. edulis, the "young mushrooms seemed to contain more $\mathrm{Hg}$ then older ones," based on dry weight. Similarly, Nasr and Arp (2011) and Nasr et al. (2012) examined THg in carpophores of 27 species of macrofungi and noted a significant decline in THg (dry weight data) from emergence to senescence in 26 species, except, curiously, B edulis. For B. edulis, concentration of $\mathrm{THg}$ in carpophores increased from emergence to mature and to senescence developmental stage (Nasr and Arp 2011). It seems possible that the description of "young mushrooms" or "emergence" developmental stage in cited studies could be different from the "button stage" in the current study. Here, unlike Nasr et al. (2012), no such correlation has been observed; however, large fruiting bodies with yellow hymenophore were still perfect for consumption. In a study of Amanita muscaria (L.) Lam., the THg concentrations in carpophores were similar regardless of their developmental stage from the bottom size to fully mature but not at a "rotting" condition (six size classes) (Hanć et al. 2021).

\section{MeHg, braising, and carpophore developmental pattern}

The overall mean $\mathrm{MeHg}$ concentration in braised meals across all the developmental stages was $0.0053 \pm 0.0022 \mathrm{mg} \mathrm{kg}^{-1}$ ww, while that for the unprocessed (raw) mushrooms was $0.0042 \pm 0.0010 \mathrm{mg} \mathrm{kg}^{-1} \mathrm{ww}$. The MeHg content of a braised meal made of the button stage carpophores was $0.0089 \pm$ $0.0001 \mathrm{mg} \mathrm{kg}^{-1} \mathrm{ww}$ but this concentration decreased in the higher developmental stages in which the overall mean was $0.0041 \pm 0.0019 \mathrm{mg} \mathrm{kg}^{-1}$ ww (difference statistically significant; $p<0.0001 ; \mathrm{M}-\mathrm{W} U$ test). Braising resulted in increase of $\mathrm{MeHg}$ in mushroom meals by $53 \pm 122 \%$ whole (wet) weight (a decrease by $40 \pm 49 \%$ on dry weight basis) but these differences were variable between the different stages (Table 3). The raw dehydrated carpophores across all developmental stages showed $\mathrm{MeHg}$ at concentration of $0.0425 \pm 0.0101 \mathrm{mg} \mathrm{kg}^{-1} \mathrm{dw}$ with much lower concentrations in the braised counterparts, i.e., $0.0209 \pm 0.0084 \mathrm{mg} \mathrm{kg}^{-1} \mathrm{dw}$.

The braised mushrooms in this experiment, as already mentioned, retained some amount of fatty residue (around 5 to $7 \%$ ww) which has a diluting effect on the basic constituents retained. Usually, apart from fat (butter or vegetable oil), recipes for braised mushrooms can also include a variety of vegetables and spices but also meat. However, the basic meal of B. edulis and butter or olive oil is adequate as a meal. Notably, domestic drying of fungal carpophores (traditionally, mushrooms are roughly sliced and dried in partial sunshine-a common technique to preserve edible wild mushrooms around the world), regardless of the manner, always leads to the preconcentration at almost tenfold high rate of solids, i.e., the constituents that are "nonvolatile" at a given temperature regime.

The MeHg contribution to $\mathrm{THg}$ in crude and braised carpophores of $B$. edulis regardless of the developmental stage was low, i.e., at $1.9 \pm 0.7 \%$ in crude and $1.4 \pm 0.3 \%$ in braised product and did not show any tendency to increase or decrease during development (Table 3). In this study, the scale of the $\mathrm{MeHg}$ contribution to THg in raw B. edulis carpophores was 
evidently lower when compared to results from other studies described in the "Introduction" section. In a most recent study of composite samples of a dried caps, stipes and whole fruiting bodies of $B$. edulis from a several sites, the MeHg contribution to $\mathrm{THg}$ was in the range from 0.50 to $4.9 \%$ (Rutkowska et al. 2021). The scientific literature lacks data on $\mathrm{MeHg}$ for culinary processed mushrooms. At the button stage, B. edulis showed higher $\mathrm{MeHg}$ concentrations than crude sample, which might suggest better retention during braising, but this pattern was not seen for the higher developmental stages (Table 3).

For human consumption, the provisional tolerable weekly intake (PTWI) of inorganic $\mathrm{Hg}(\mathrm{iHg})$ is $0.004 \mathrm{mg} \mathrm{kg}^{-1}$ body mass (bm) and of MeHg is $0.0016 \mathrm{mg} \mathrm{kg}^{-1} \mathrm{bm}$ (World Health Organization 2007), i.e., $0.280 \mathrm{mg}$ of $\mathrm{iHg}$ and $0.112 \mathrm{mg}$ of $\mathrm{MeHg}$ for a person of $70 \mathrm{~kg} b \mathrm{bm}$ per week. In this study, consumption of a $100 \mathrm{~g}$ meal of braised $B$. edulis once in a week would result in a total $\mathrm{MeHg}$ intake of $0.00053 \pm$ $0.00022 \mathrm{mg}$, and $0.03604 \pm 0.00915 \mathrm{mg}$ of $\mathrm{THg}$, which are both well below the PTWI.

Mushrooms are organisms that are capable of absorption and high bio-concentration of $\mathrm{Hg}$, but at the same time, they are also relatively rich in selenium (Se), which is an antagonist of $\mathrm{Hg}$. This is seen in many species, particularly from the family Boletaceae and including B. edulis. Thus, apart from a small and considered as safe in this study, for human consumers, the potential intakes of $\mathrm{THg}$ and $\mathrm{MeHg}$ from braised meals of $B$. edulis studied were small and considered safe, but the Se content could be considered as an additional parameter preventing adverse effects from both $\mathrm{Hg}$ compounds. However, this was not included in the present study.

\begin{abstract}
Author contributions Conceptualization, methodology, resources, formal analysis, data curation, writing original draft preparation, review and editing, supervision, Jerzy Falandysz; Investigation, resources, formal analysis, Martyna Saba; Methodology, resources, investigation, formal analysis, data curation, Malgorzata Rutkowska; data curation, supervision, Piotr Konieczka.
\end{abstract}

Funding This study had part financial support by the National Science Centre under grant no. UMO-2016/23/N/NZ9/02746.

Data availability Not applicable.

\section{Declarations}

Ethical approval This article does not contain any studies with human participants or animals performed by any of the authors.

Consent to participate Not applicable. This manuscript does not contain any studies with human participants or animals performed by any of the authors.

Consent to publish Not applicable. This manuscript does not contain any individual person's data in any form.
Conflict of interest The authors declare no competing interests.

Open Access This article is licensed under a Creative Commons Attribution 4.0 International License, which permits use, sharing, adaptation, distribution and reproduction in any medium or format, as long as you give appropriate credit to the original author(s) and the source, provide a link to the Creative Commons licence, and indicate if changes were made. The images or other third party material in this article are included in the article's Creative Commons licence, unless indicated otherwise in a credit line to the material. If material is not included in the article's Creative Commons licence and your intended use is not permitted by statutory regulation or exceeds the permitted use, you will need to obtain permission directly from the copyright holder. To view a copy of this licence, visit http://creativecommons.org/licenses/by/4.0/.

\section{References}

Alonso J, Salgado MJ, García MA, Melgar MJ (2000) Accumulation of mercury in edible macrofungi: influence of some factors. Arch Environ Contam Toxicol 38:158-162

Árvay J, Tomáša J, Hauptvogl M, Kopernická M, Kováčik A, Bajčan D, Massányi P (2014) Contamination of wild-grown edible mushrooms by heavy metals in a former mercury-mining area. J Environ Sci Health B 49:815-827

Bargagli R, Baldi F (1984) Mercury and methyl mercury in higher fungi and their relation with substrata in a cinnabar mining area. Chemosphere 13:1059-1071

Brambilla G, Abete MC, Binato G, Chiaravalle E, Cossu M, Dellatte E, Miniero R, Orletti R, Piras P, Roncarati A, Ubaldi A, Chessa G (2013) Mercury occurrence in Italian seafood from the Mediterranean Sea and possible intake scenarios of the Italian coastal population. Regul Toxicol Pharmacol 65:269-277

Drewnowska M, Falandysz J, Chudzińska M, Hanć A, Saba M, Barałkiewicz D (2017) Leaching of arsenic and sixteen metallic elements from Amanita fulva mushrooms after food processing. LWT Food Sci Technol 84:861-866

Falandysz J (2013) Review: on published data and methods for selenium in mushrooms. Food Chem 138:242-250

Falandysz J (2016) Mercury bio-extraction by fungus Coprinus comatus: a possible bioindicator and mycoremediator of polluted soils. Environ Sci Pollut Res 23:7444-7451

Falandysz J (2017) Mercury accumulation of three Lactarius mushroom species. Food Chem 214:96-101

Falandysz J, Drewnowska M (2015) Distribution of mercury in Amanita fulva (Schaeff.) Secr. mushrooms: accumulation, loss in cooking and dietary intake. Ecotoxicol Environ Saf 115:49-54

Falandysz J, Drewnowska M (2017) Cooking can decrease mercury contamination of a mushroom meal: Cantharellus cibarius and Amanita fulva. Environ Sci Pollut Res 24:13352-13357

Falandysz J, Dryżałowska A, Zhang J, Wang Y (2019b) Mercury in raw mushrooms and mushrooms stir-fried in deep oil. J Food Compos Anal 82:103239

Falandysz J, Frankowska A, Jarzyńska G, Dryżałowska A, Kojta AK, Zhang D (2011) Survey on composition and bioconcentration potential of 12 metallic elements in King Bolete (Boletus edulis) mushroom that emerged at 11 spatially distant sites. J Environ Sci Health B 46:231-246

Falandysz J, Frankowska A, Mazur A (2007) Mercury and its bioconcentration factors in King Bolete (Boletus edulis) Bull. J Environ Sci Health A Tox Hazard Subst Environ Eng 42:20892095

Falandysz J, Gucia M, Frankowska A, Kawano M, Skwarzec B (2001) Total mercury in wild mushrooms and underlying soil substrate 
from the city of Umeå and its surroundings, Sweden. Bull Environ Contam Toxicol 67:763-770

Falandysz J, Kunito T, Kubota R, Bielawski L, Frankowska A, Falandysz JJ, Tanabe S (2008) Multivariate characterization of elements accumulated in King Bolete Boletus edulis mushroom at lowland and high mountain regions. J Environ Sci Health A 43:1692-1699

Falandysz J, Lipka K, Gucia M, Kawano M, Strumnik K, Kannan K (2002) Accumulation factors of mercury in mushrooms from Zaborski Lndscape Park, Poland. Environ Int 28:421-427

Falandysz J, Lipka K, Kawano M, Brzostowski A, Dadej M, Jędrusiak A, Puzyn T (2003) Mercury content and its bioconcentration factors in wild mushrooms at Łukta and Morag, northeastern Poland. J Agric Food Chem 51:2832-2836

Falandysz J, Mazur A, Drewnowska M, Kojta AK, Jarzyńska G, Dryżałowska A, Nnorom IC (2013) Mercury in fruiting bodies of dark honey fungus (Armillaria solidipes) and beneath substratum soils collected from spatially distant areas. J Sci Food Agric 93: 853-858

Falandysz J, Mędyk M, Saba M, Zhang J, Wang Y, Li T (2020b) Mercury in traditionally foraged species of fungi (macromycetes) from the karst area across Yunnan province in China. Appl Microbiol Biotechnol 104:9421-9432

Falandysz J, Meloni D, Fernandes AR, Saniewski M (2021a) Effect of drying, blanching, pickling and maceration on the fate of $40 \mathrm{~K}$, total $\mathrm{K}$ and $137 \mathrm{Cs}$ in bolete mushrooms and dietary intake. Environ Sci Pollut Res. https://doi.org/10.1007/s11356-021-15523-9

Falandysz J, Saba M, Strumińska-Parulska D (2021b) ${ }^{137}$ Caesium, ${ }^{40} \mathrm{~K}$ and total $\mathrm{K}$ in Boletus edulis at different maturity stages: effect of braising and estimated radiation dose intake. Chemosphere 268: 129336

Falandysz, Shi J, Monti C (2020a) Environmental cycling and fate of mercury: 2020. Chemosphere 261:127766

Falandysz J, Zhang J, Mędyk M, Zhang X (2019a) Mercury in stir-fried and raw mushrooms from the Boletaceae family from the geochemically anomalous region in the Midu county, China. Food Control 102:17-21

Falandysz J, Zhang J, Wang Y, Saba M, Krasińska G, Wiejak A, Li T (2015) Evaluation of the mercury contamination in fungi Boletus species from latosols, lateritic red earths, and red and yellow earths in the Circum-Pacific Mercuriferous Belt of Southwestern China. PLoSONE 10(11):e0143608. https://doi.org/10.1371/journal.pone. 0143608

Fischer RG, Rapsomanikis S, Andreae MO, Baldini F (1995) Bioaccumulation of methylmercury and transformation of inorganic mercury by macrofungi. Environ Sci Technol 29:993-999

Frankowska A, Ziółkowska J, Bielawski L, Falandysz J (2010) Profile and bioconcentration of minerals by King Bolete (Boletus edulis) from the Płocka Dale in Poland. Food Addit Contam Part B Surveill $3: 3-6$

Gucia M, Falandysz J (2003) Total mercury content in Parasol Mushroom Macrolepiota procera from various sites in Poland. J Phys IV 107: 581-584

Gumińska B, Wojewoda W (1985) Grzyby i ich oznaczanie. Państwowe Wydawnictwo Rolnicze i Leśne (Wydanie III) Warszawa

Gustin M, Lindberg S, Marsik F, Casimir A, Ebinghaus R, Edwards G, Hubble-Fitzgerald C, Kemp R, Kock H, Leonard T, London J, Majewski M, Montecinos C, Owens J, Pilote M, Poissant L, Rasmussen P, Schaedlich F, Schneeberger D, Schroeder W, Sommar J, Turner R, Vette A, Wallschlaeger D, Xiao Z, Zhang H (1999) Nevada STORMS project: measurement of mercury emissions from naturally enriched surfaces. J Geophys Res 104:2183121844

Hanć A, Falandysz J, Fernandes AR, Zhang J (2021) Mercury and selenium in developing and mature fruiting bodies of Amanita muscaria. Environ Sci Pollut Res. https://doi.org/10.1007/s11356021-14740-6
Harada M (1995) Minamata disease: methylmercury poisoning in Japan caused by environmental pollution. Crit Rev Toxicol 25:1-24

Heleno SA, Ferreira RC, Antonio AL, Queiroz M-JRP, Barros L, Ferreira ICFR (2015) Nutritional value, bioactive compounds and antioxidant properties of three edible mushrooms from Poland. Food Biosci 11:48-55

Jarzyńska G, Chojnacka A, Dryżałowska A, Nnorom IC, Falandysz J (2012) Concentrations and bioconcentration factors of minerals in yellow-cracking bolete (Xerocomus subtomentosus) mushroom collected in Noteć Forest, Poland. J Food Sci 77:H202-H206. https:// doi.org/10.1111/j.1750-3841.2012.02876.x

Kavčič A, Mikuš K, Debeljak M, Teun van Elteren J, Arčon I, Kodre A, Kump P, Karydas AG, Migliori A, Czyżycki M, Vogel-Mikuš K (2019) Localization, ligand environment, bioavailability and toxicity of mercury in Boletus spp. and Scutiger pes-caprae mushrooms. Ecotoxicol Environ Saf 184:109623

Kojta AK, Falandysz J (2016) Soil-to-mushroom transfer and diversity in total mercury content in two edible Laccaria mushrooms. Environ Earth Sci 75:1-7

Kojta AK, Wang Y, Zhang J, Li T, Saba M, Falandysz J (2015) Mercury contamination of fungi genus Xerocomus in the Yunnan Province in China and the region of Europe. J Environ Sci Health A 50:13421350

Krasińska G, Falandysz J (2016) Mercury in Orange Birch Bolete Leccinum versipelle and soil substratum: bio-concentration by mushroom and probable dietary intake by consumers. Environ Sci Pollut Res 23:860-869

Le Croizier G, Lorrain A, Schaal G, Ketchum J, Point D (2020) Trophic resources and mercury exposure of two silvertip shark populations in the northeast Pacific Ocean. Chemosphere 253:126645

Maggi C, Berducci MT, Bianchi J, Giani M, Campanella I (2009) Methylmercury determination in marine sediment and organisms by direct mercury analyser. Anal Chim Acta 641:32-36

Melgar MJ, Alonso J, García MÁ (2009) Mercury in edible mushrooms and soil. Bioconcentration factors and toxicological risk. Sci Total Environ 407:5328-5334

Nasr M, Arp PA (2011) Hg concentrations and accumulations in fungal fruiting bodies, as influenced by forest soil substrates and moss carpets. Appl Geochem 26:1905-1917

Nasr M, Malloch DW, Arp PA (2012) Quantifying Hg within ectomycorrhizal fruiting bodies, from emergence to senescence. Fungal Biol 116:1163-1177

Nawrocka A, Durkalec M, Szkoda J, Filipek A, Kmiecik M, Żmudzki J, Posyniak A (2020) Total mercury levels in the muscle and liver of livestock and game animals in Poland, 2009-2018. Chemosphere 258:127311

Nnorom IC, Jarzyńska G, Drewnowska M, Kojta AK, Pankavec S, Falandysz J (2013) Trace elements in sclerotium of Pleurotus tuber-regium (Ósu) mushroom - dietary intake and risk in Southeastern Nigeria. J Food Compos Anal 29:73-81

Petrova MV, Ourgauda M, Boavida JRH, Dufour A, Onrubia JAT, Lozingota A, Heimbürger-Boavida L-E (2020) Human mercury exposure levels and fish consumption at the French Riviera. Chemosphere 258:127232

Ralston NVC, Raymond LJ (2018) Mercury's neurotoxicity is characterized by its disruption of selenium biochemistry. Biochim Biophys Acta Gen Subj 1862:2405-2416

Rieder SR, Brunner I, Horvat M, Jacobs A, Frey B (2011) Accumulation of mercury and methylmercury by mushrooms and earthworms from forest soils. Environ Pollut 159:2861-2869

Rutkowska M, Falandysz J, Saba M, Szefer P, Misztal-Szkudlińska M, Konieczka P (2021) Determination of total mercury and monomethylmercury in samples of fungi from different regions of the world. Submitted 
Saba M, Falandysz J (2021) The effects of different cooking modes on the ${ }^{137} \mathrm{Cs},{ }^{40} \mathrm{~K}$ and total $\mathrm{K}$ content in Boletus edulis (King Bolete) mushrooms. Environ Sci Pollut Res 28:12441-12446

Saba M, Falandysz J, Nnnorom IC (2016) Evaluation of vulnerability of Suillus variegatus and Suillus granulatus mushrooms' to sequester mercury in fruiting bodies. J Environ Sci Health B 51:540-545

Schwesig D, Ilgen G, Matzner E (1999) Mercury and methylmercury in upland and wetland acid forest soils of a watershed in NE-Bavaria, Germany. Water Air Soil Pollut 113:141-154

Seeger (1976) Die Verteilung des Quecksilbers in den Fruchtkőpren von Steinpilzen und Champignons. Z Lebensm Unters Forsch 161:115117

Širić I, Falandysz J (2020) Contamination, bioconcentration and distribution of mercury in Tricholoma spp. mushrooms from Southern and Northern regions of Europe. Chemosphere 251:126614

Širić I, Kasap A, Bedeković D, Falandysz J (2017) Lead, cadmium and mercury contents and bioaccumulation potential of wild edible saprophytic and ectomycorrhizal mushrooms. J Environ Sci Health B 52:156-165

Spiller HA (2018) Rethinking mercury: the role of selenium in the pathophysiology of mercury toxicity. Clin Toxicol (Phila) 56:313-326. https://doi.org/10.1080/15563650.2017.1400555

Stijve T, Roschnik R (1974) Mercury and methyl mercury content of different species of fungi. Trav Chim Aliment Hyg 65:209-220

Svoboda L, Kalač P, Špička J, Janoušková D (2002) Leaching of cadmium, lead and mercury from fresh and differently preserved edible mushroom, Xerocomus badius, during soaking and boiling. Food Chem 79:41-45

Villar E, Cabrol L, Heimbürger-Boavida LE (2020) Widespread microbial mercury methylation genes in the global ocean. Environ Microbiol Rep 12:277-287. https://doi.org/10.1111/17585662229.12829

Wiejak A, Wang Y-Z, Zhang J, Falandysz J (2016) Mercury in sclerotia of Wolfiporia extensa (Peck) Ginns fungus collected across of the Yunnan land. Spectrosc Spectral Anal 36:3083-3086

World Health Organization (2007) Evaluations of the Joint FAO/WHO Expert Committee on Food Additives (JECFA). METHYLMERCURY. http://apps.who.int/food-additivescontaminants-jecfa-database/chemical.aspx? chemID $=3083$ (retrieved on Jun 25, 2020)

Xu J, Buck M, Eklöf K, Ahmed OO, Schaefer JK, Bishop K, Skyllberg U, Björn E, Bertilsson S, Bravo AG (2019) Mercury methylating microbial communities of boreal forest soils. Sci Rep 9:518. https:// doi.org/10.1038/s41598-018-37383-z

Zhou J, Du B, Shang L, Wang Z, Cui H, Fan X, Zhou J (2020) Mercury fluxes, budgets, and pools in forest ecosystems of China: A review. Crit Rev Environ Sci Technol 50:1411-1450

Publisher's note Springer Nature remains neutral with regard to jurisdictional claims in published maps and institutional affiliations. 